\title{
Comparative Introduction to Socionomy and Psychonomy
}

\author{
Charles Ogundu Nnaji \\ Department of Philosophy and Religions, University of Abuja, Abuja, Nigeria \\ Email: economos34@yahoo.com
}

Received 20 October 2014; accepted 23 March 2015; published 26 March 2015

Copyright (C) 2015 by author and Scientific Research Publishing Inc.

This work is licensed under the Creative Commons Attribution International License (CC BY). http://creativecommons.org/licenses/by/4.0/

(c) (i) Open Access

\begin{abstract}
Socionomy and psychonomy coined by this author primarily teach the philosophical origins and true meaning of sociology from 18th century CE philosophical arguments that human societies can exist and survive without religion and God. Following this existing study framework, the research aims at proving that sociology and sociologists do not or have not really understood the true origin and true meaning of sociology, which through this research objectives and conclusions, clearly show that sociology is an anti-God so-called positivist philosophy of science that condemns the thirty-year Protestant-Catholic wars by totally condemning religion and God without adequately analyzing the roles of human religious psychology (psychonomy) and human doctrine in the entire saga.
\end{abstract}

\section{Keywords}

Socionomy, Psychonomy, Sociology, Christianity, Religion, CE

\section{Analytical General Introduction}

Mckee (1981) defined sociology as the study of human societies, however, sociology NET traces the origins of modern sociology from philosophical arguments of French philosopher Auguste Comte (1758) to Karl Marx (1818) and Englishman Herbert Spencer (1903) whose arguments in related philosophy of science tagged religion as a social problem and a conjecture without which human societies could exist.

Ogundu (2000) identified many psycho-social causes of suicides which dented the ability of human societies to exist without God and religion in matters of spiritual counseling and divine interventions in the treatment and prevention of suicides.

Mckee (1981) clearly stated that the age of science and technology would reach its peak (i.e. diminishing returns) after which religion and spirituality would gradually make a very strong return to human problem solving 
strategies. But then, what were the origins of those philosophical arguments that human societies could exist without religion and God? Brockman \& Pescantini (1991) reviewed by Njure (2004) recorded the ProtestantCatholic wars which decimated medieval and enlightenment Europe between 1531 and $1648 \mathrm{CE}$, which sowed seeds of hatred against religion in Europe (Schaff, 1962), not forgetting the Muslim invasions of Europe and the earlier Christian crusades in defense of Europe and Jerusalem (Boer, 1969). By 1648 CE the 30 years (senseless) Protestant-Catholic wars had ended, while Otto Von Bismarck conquered Catholic and Protestant Gothic territories to make modern Germany in 1870. However, in France, the French Revolution of 1798 attempted to destroy Christianity out of France (Brockman, 1991). From France arose August-Comte who developed philosophical arguments against religion.

The Marxist anti-God theories of Karl Marx followed echoing debates from philosophy of science and positivism, then to empiricism and logical positivism, all of which argued against phenomena which could not be empirically or physically verified (Ogundu, 1994). More philosophical attacks on religion came from French man Edmund Husserl under phenomenology which dismissed very and anything which the human mind and the eye cannot see and verify (Oyeshile \& Ugwuanyi, 1997). Nwala (1997) had cited British analytical philosopher Bertrand Russel who stated that philosophy distanced itself from religion while claiming to be scientific; however science rejected philosophy on the basis that philosophy's methods were based solely on human reasoning rather than on scientific observation and experiment. From this point, socionomy made its entry squarely confront the philosophical insinuations which formed sociology, namely, man could exist without religion and God).

\section{Objective of This Study}

The study introduces socionomy and psychonomy as new fields of studies which reveal the true meaning and true origins of sociology which lay in European 1700/1800 CE anti-God philosophical empiricism, phenomenology and positivism which strongly argued against God and religion, particularly that Religion is a social problem rather than a solution to social conflicts. Hence, the positivist argument was that society can do without religion, this which is the true meaning and origin of sociology (see Sociology NET, 2012, on Auguste Comte's Philosophy of Science).

\section{The Problem of This Study}

\subsection{What Is the Difference between Sociology and Theology?}

Western scholars have falsified so many facts regarding ecclesiastical origins of our modern science and technology civilization. For example western (European) scholars will never tell you that Economos (i.e. Economics) means Temple administration from the Hebrew "Hekon" (i.e. Temple) (BDB, 2007) neither will they tell you that Banking is from the Hebrew "Korbanan" i.e. Temple Treasury (Brown \& Comfort, 1990), let alone will they tell you that the true origins of philosophy is from the Old Testament Hebrew "Philasaphim" (Exodus 7:11) which means magicians or finding out things through magic (Hebrew, 2005). Thus, the point being made is that this study may find it difficult convincing people that the real intentions of producing the field called sociology was to kill the ancient field called Theology.

Theology means the study of God, however those who produced sociology actually had an ideological plan to push Europe away from monasticism and the study of God (i.e. Theology) so that Europe will study society rather than studying God, particularly, studying society which has no place for God and Religion (Brockman \& Pescantini, 1991).

\subsection{Academic Relevance of Socionomy}

Socionomy encourages academic brainstorming and consistent collection and analysis of data to actually prove or disprove if human societies can do without religion and God, particularly to find out if there are currently societies, who do not believe in God and Religion, and if they are better off than religious societies.

\subsection{Definition of Terms}

\subsubsection{Socionomy}

Nnaji Charles Ogundu introduced the word "Socionomy" in the "Theistic and Socionomic Origins of Philoso- 
phy" (2013) which means that Philosophy which has related religious origins now says that Religion has become a social problem. Particularly, how Europe rejected the control of European societies by the Holy Roman Catholic Empire. Europe did this through Protestantism also called Church Reformation of 1517 to 1648 CE: Note, Graeco-Latin "Socius" from Greek "Suzao" (to live together) and Nomos (sacred laws) or sacred customs gave us the word "socionomy" i.e. societies controlled by religious principles (see the Journal of Analytical Socionomy and Psychonomy).

\subsubsection{Psychonomy}

Nnaji (2013) in the Journal of Analytical Socionomy and Psychonomy as a recent coinage by Charles OgunduNnaji (2011) which simply means abnormal religious mentality, particularly Biochemistry-Religion which emphasizes the investigation of the mentality and reasoning of people who abnormally practice Religion, rather than wasting time on Philosophy of Religion which wrongly investigates the truth in Religion, especially if God (and gods) exist or not.

1) Psychonomy was coined by this author (Nnaji, 2014) from the New Testament Greek "Psuxe (Psyche i.e. soul or inner life, "or seat of human behavior", merged with the Greek "Naon" to the Greek "Nomon" i.e. the sacred, Spiritual or sacred Jewish law (Aland \& Newman, 1983: pp. 116-120).

2) Psychonomy argues that it is better to investigate the mentality of those practicing religion in such abnormal way that portrays religion as evil (or blood thirsty), since right thinking people can practice a bad religion in such a sane manner, which makes religion look good, while mentally-disturbed people can make a good religion look evil. Please see Charles Ogundu Nnaji, on Christian Psychology, (Ogugua, 2013, editor, the Journal of Philosophy, Nnamdi Azikiwe University, 2013).

3) Psychonomy, thus means faulty religious mentalities which create serious social problems; particularly that the human brain produces and controls religious behavior, especially violent, corrupt and criminal minded religious behavior: i.e. people are religious yet they are worldly, corrupt, criminal and violent. They are often attracted more by worldly things or items. Society is massively religious and spiritual yet, it is corrupt, criminal, violent and worldly minded.

\subsubsection{Sociology}

In relation to socionomy, sociology is from the Latin "socius" (i.e. N.T Greek "suzao") which means to live together (Aland \& Newman, 1983) while "logia" is from the N.T Greek "logos" which means spoken word or argument (Metzger, 2001). Simpson \& Weiner(1989) and Mckee (1981) defined Sociology as the study of human societies which includes social institutions such as educational bodies, Religion and its establishments, public utilities like the arts theatre, sports stadia, rehabilitation homes, orphanages, civil societies like non governmental bodies, not forgetting the interaction of culture, politics, religion, and business in human communities, etc.

\subsubsection{Christianity}

Christianity is from the Greek Xristianos which means followers of Christ, i.e. a Jewish Rabbi or teacher who lived and worked miracles in Galilee of Palestine, Judea, around 3 BCE. These records are detailed in early church histories (Boer, 1969).

\subsubsection{Religion}

Religion is from the Latin Religere which implies to bind or form a habit of something, particularly something one cannot do without, which means that Religion does not necessarily have to do with the supernatural (Eliade, 1989).

C.E: C.E means Christian Era (some prefer Common Era). Since people misuse A.D as "after the death of Christ", rather as Anno Domino, i.e. in the year of our Lord, we decided to change it to C.E, Christian Era.

\subsection{Method of Data Collection}

Please Note that this study adopts the Christian Statistics Data Analyses Collection Method. Christian Statistics states that research studies in religions must be backed up by collected and analyzed physical data (Nnaji, 2013) (Table 1 and Table 2).

1) See Sandra (1993): Discovering the Human Brain, and Mann M. and Stanley (1984) in The Psychonomy of 
Table 1. Analyzed data of development index in religious and irreligious countries.

\begin{tabular}{ccccc}
\hline Country & Religious & Irreligious & Morality & Financial Morality \\
\hline France & $25 \%$ & $60 \%$ & $55 \%$ & $60 \%$ \\
China & $65 \%$ & $30 \%$ & $55 \%$ & $65 \%$ \\
Cameroun & $75 \%$ & $20 \%$ & $38 \%$ & $35 \%$ \\
Saudi Arabia & $90 \%$ & $08 \%$ & $50 \%$ & $65 \%$ \\
Egypt & $50 \%$ & $35 \%$ & $45 \%$ & $45 \%$ \\
Nigeria & $93 \%$ & $07 \%$ & $35 \%$ & $15 \%$ \\
USA & $70 \%$ & $25 \%$ & $65 \%$ & $80 \%$ \\
Australia & $70 \%$ & $21 \%$ & $80 \%$ & $85 \%$ \\
Poland & $65 \%$ & $30 \%$ & $65 \%$ & $65 \%$ \\
Britain & $55 \%$ & $40 \%$ & $70 \%$ & $80 \%$ \\
South Korea & $60 \%$ & $30 \%$ & $60 \%$ & $65 \%$ \\
Japan & $65 \%$ & $30 \%$ & $70 \%$ & $80 \%$ \\
South Africa & $60 \%$ & $35 \%$ & $50 \%$ & $55 \%$ \\
Russia & $45 \%$ & $50 \%$ & $40 \%$ & $45 \%$ \\
Qatar & $65 \%$ & $25 \%$ & $65 \%$ & $60 \%$ \\
\hline
\end{tabular}

(a) See british broadcasting corporation, 2011 publics opinion polls; (s) Transparency international reports-2012.

Table 2. Mental health issues in religions.

\begin{tabular}{|c|c|c|c|}
\hline Psychiatry & Psychology & Revelation & Consequences \\
\hline $\begin{array}{l}\text { Paul Schilder (1962) contributions } \\
\text { to Neuropsychiatry. }\end{array}$ & $\begin{array}{l}\text { Richard Atkinson (1990) } \\
\text { introduction to psychology }\end{array}$ & $\begin{array}{l}\text { Thomas Hobbes } \\
\text { (1669) in Leviathan }\end{array}$ & \\
\hline $\begin{array}{l}\text { Cases Studies } \\
\text { Religious schizoids, i.e. hearing } \\
\text { voices and seeing things e.g. girl } \\
\text { who heard the voice of her god } \\
\text { instructing her to jump into } \\
\text { burning fire for purification }\end{array}$ & $\begin{array}{l}\text { Case studies } \\
\text { Abnormal deviant anti-social } \\
\text { religious behavior, i.e. extremist } \\
\text { mis-interpretation of religious } \\
\text { scriptures e.g. Iranian Shiites } \\
\text { flogging blood out of their } \\
\text { bodies as acts of penance }\end{array}$ & $\begin{array}{l}\text { Case study } \\
\text { Madmen will not let } \\
\text { us know who is a } \\
\text { prophet and who is } \\
\text { not a madman }\end{array}$ & $\begin{array}{l}\text { Extremist and violent religious } \\
\text { behaviors } \\
\text { Senseless religious practices. } \\
\text { Outrageous intolerance, etc. }\end{array}$ \\
\hline
\end{tabular}

Suicide; cited by Ogundu (2000) Philosophical and Religious Analysis of Suicide (Ibadan Ph.D. Thesis).

2) See also the American Mental Health Yearly Index.

\subsection{Relationship between Socionomy and Psychonomy}

As noted in this study's abstract, socionomy and psychonomy are related concepts. Psychonomy from our definition of terms implies violent religious mentality and decisions and actions dictated by narrow-minded religious beliefs and indoctrinations which often end up producing related religious social problems. Hence, socionomic studies must always have in mind that precursors or causes of socio-religious problems often lie in primordial psychonomic (unreasoning) narrow-minded religious extremism. In other words, psychonomy focuses more on Biochemical correlates in the possible genetic origin of violent religious behavior particularly its impacts on society and social reactionary solutions to it, which are often armed forces in nature rather than theological Dialectical methods which many people claim cannot solve violent religious behaviors.

\section{Brief Background to Socionomy}

\section{The History of Christianity Is the History of Europe}

Weber (1905) stated that Protestantism produced capitalism (see Marx (1905) on the Protestant Ethic and the Spirit of Capitalism). But then, what is Protestantism?

From 1300 to $1400 \mathrm{CE}$, Hussites and Wycliffes were in renaissance Europe agitating for moral reforms in the 
Roman Latin Church. Some of the agitators were silenced. However by 1517, a German Revd Father called Martin Luther pasted his 95-thesis, protest against the church. The thesis was pasted on the walls of his Church at Ensleben in Germany. By 1520, Emperor Charles invited Luther for questioning; less than four months later the Pope from Rome issued his papal Bull excommunicating Martin Luther from the Church, that which started the Protestant revolution against Roman Catholicism, that which also shattered the Holy Roman Catholic Empire which held Europe together for over 1000 years. Those over 100-year wars and rebellions in the church which destroyed the Catholic Empire gave different European nation states and regions their freedom from the Holy Roman Catholic Empire. Hence, England, France, Germany, Denmark, Spain, etc. no more lived under the Roman Empire, but they gained their independence. However the animosities from the break-up of the Roman Catholic Empire, led to the first and second world wars since Germany believed that many territories like Poland, Austria and France etc were German (see Schaff, 1962; Brockman \& Pescantini 1991; Njure 2004; Bainton, cited by Church Reformation NET, Boer, 1976).

\section{Conclusion and Research Findings}

1) From the foregoing, particularly noting our definition of terms, psychonomy argues that conceptually religion is not a problem, rather narrow-minded, extremist and violent mentalities of fanatical adherents of religion, consistently perpetrates crimes against humanity in the name of religion. Being the reason why the Rabbi of London stated that all those who kill and martyr in the name of God, on the promise of paradise should be told that they are already in hell fire (see Ogundu (2000) "A Philosophical and Religious Analyses of Suicide").

2) Socionomy as a field of study really has nothing against sociology, and rather aims at stating that sociology, originally from its Comtean and Marxist etc. origins, were not really all in all about studying human societies; rather 18th and 19th century empiricists, positivists and philosophers who labeled religion a problematic conjecture, in truth, wanted human societies without religion and God (Sociology NET, 2012).

Future studies are also expected to work on why societies are massively religious and spiritual, yet they are massively worldly, corrupt, criminal and violent.

\section{References}

Boer, H. (1969). A Brief History of Islam (Ibadan; Michigan; Eerdmans).

Brockman, R., \& Pescantini (1991). A History of the Catholic Church. Reviewed by Stephen Njure in 2004 (Nairobi, Paulines).

Brown, P., \& Comfort, W. (1990). The Interlinear Greek-English New Testament (Illinois Baker).

Eliade, M. (1989). Encyclopaedia of Religion (Vol. 23). New York.

Hebrew (2005). The Old Testament Hebrew-English Lexicon. Massachusetts: Hendrickson.

Marx, W. (1905). Protestantism and the Spirit of Capitalism. Journal of Comparative Religion, 2.

Mckee, J. (1981). Sociology. New York, Rhinehart and Wiston: Studies of Society.

Nwala, T. U. (1997). Introduction to Philosophy (Nsukka; Fap).

Ogundu, C. O. (1994). The Validity of Truth in Counter-Claims. Ibadan M.A. Dissertation.

Ogundu, C. O. (2000). A Philosophical and Religious Analyses of Suicide. Ibadan Ph.D. Thesis.

Oyeshile, O. A., \& Ugwuanyi, L. O. (1997). Elements of Philosophy (Benin; Timeless).

Sandra, A. (1993). Discovering the Human Brain, and Mann M.

Schaff, P. (1962). History of the Church. London: Reformation NET.

Stanley, J. (1984). Cited in The Psychonomy of Suicide by Ogundu, C.O. (2000) and Philosophical and Religious Analysis of Suicide (Ibadan Ph.D. Thesis).

Wikipedia "Sociology" (2012). General Introduction to Psychonomy and Socionomy. Awka: NAU. 